\title{
Shadow Teacher Social Interaction Problem in SDN of Gadang 2 Banjarmasin
}

\author{
Imam Yuwono \\ Inclusive Education \\ Faculty of Teaching and Education \\ Universitas Lambung Mangkurat \\ Banjarmasin, Indonesia
}

\author{
Utomo, Agus Pratomo Andi Widodo \\ Inclusive Education \\ Faculty of Teaching and Education \\ Universitas Lambung Mangkurat \\ Banjarmasin, Indonesia
}

\begin{abstract}
Inclusive education is an education service system that provides opportunities for all children to study together in a public school with attention to diversity and individual needs. Educational services for Special Needs Children are done by shadow teachers. But in the handling of inclusive schools many problems faced by shadow teachers. The purpose of this research is to know the problem of social interaction shadow teachers in handling the children with special needs in SDN of Gadang 2 Banjarmasin. The approach used in this research is qualitative approach with case study research type. Sources of data in this study are shadow teachers of grade 1, grade 2 and grade 3 SDN of Gadang 2 Banjarmasin, and secondary data sources are documentation, observation. Data collection techniques in this study are interviews, observation, and documentation. Data analysis techniques use interactive analysis. The results of the study indicate that (1) shadow teachers in grades 1, 2 and 3 already understand the meaning of inclusive education (2) shadow teachers do not perform their duties and roles well, such as the absence of individualized education program (IEP) between regular teachers with shadow teachers in determining teaching materials, but there has been progressing reports of the development of students with special needs at the end semester. (3) Coordination of shadow teachers and regular teachers in dealing with special needs students is lacking, as shadow teachers are excluded from the identification and assessment process. The implementation of a flexible curriculum is not realized, because of the lack of knowledge of shadow teachers about the curriculum that suits the needs of learners.
\end{abstract}

Keywords - social interaction, problem, shadow teacher

\section{INTRODUCTION}

Inclusive education respects the diversity of any kind of difference. Inclusive education believes that every individual can develop in accordance with its potential. Through inclusive education, children with special needs are educated together with children in general in the same place with different services. Therefore, children with special needs need to be given equal opportunities and opportunities with children, in general, to get education services in nearby schools.

Education without discrimination is equal and quality education, for that various improvement efforts, continue to be done both quality and quantity so that citizens or learners have the ability to compete with other nations. In accordance with [1] on National Education System Chapter IV Article 5 states that every citizen has equal opportunity to obtain quality education, citizens who have physical, emotional, mental, intellectual, and / or social disabilities are entitled to special service education, remote or underdeveloped citizens and remote indigenous peoples are entitled to special service education, citizens with intellectual potential and special talents entitled to special education, and every citizen is entitled to the opportunity to promote lifelong education. This indicates that Indonesian citizens are entitled to a formal or non-formal education without exceptions. This Article becomes a breakthrough form of educational services for children with special needs in the form of providers of inclusive education. More operationally, this is reinforced by [2].

Schools of inclusive education should have education and education personnel who meet the required academic qualification standards and competencies. In addition to the principal, the vice principal in accordance with the field, classroom teachers, subject teachers, guidance and counseling teachers, labors, librarians, administrative staff, school hygiene workers and other personnel would be better if the school of inclusive education providers has teachers who have academic qualifications and special educational competencies. Special education teachers are teachers who have a minimum academic qualification of diplomats four (D-IV) or undergraduate (S1) higher education backgrounds with special courses or special education [3].

The problem that is often encountered in inclusive education is that teachers in conducting teaching and learning activities refer to the curriculum used by schools and do not adapt to the needs of learners with special needs, the background of shadow teachers does not match the special educational background of special programs, have skills in dealing with students with special needs, parents of children with special needs have not been able to fully accept their children attending regular schools, principals and bureaucrats 
do not fully understand the vision, mission, goals, and implementation of inclusive education [4].

Inclusive schools located in Banjarmasin city almost all have shadow teachers as companion of students with special needs in schools of inclusive education providers but the facts in the field of researchers found that the presence of shadow teachers at inclusive education schools in the city of Banjarmasin less optimal, inclusive education is a lack of knowledge about the duties and functions of shadow teachers, the absence of a special teacher counselor to work with shadow teachers in dealing with children with special needs, curriculum appropriateness, lack of coordination between special and regular teachers, special assistants who do not have the minimum academic qualifications. The inconsistency of inclusive education will result in the performance of special accompaniment teachers and special needs learners who are not handled optimally because they are not in accordance with the learning programs needed by children with special needs.

Based on observations in January 2017, at SDN of Gadang 2 Banjarmasin, seen some special needs participants who are disturbing the surrounding friends and not accompanied by shadow teachers. Based on a short interview with the principal researchers are known there are three classes identified the existence of children with special needs that is, class I, class II, and class III. Each class of children with special needs varies and is not proportional to the number of shadow teachers. Special education teachers who do not have minimum academic qualification standards with special educational background / extraordinary education are also the main problems; this has an impact on the handling of children with special needs in inclusive schools.

The problem of prolaboration of shadow teachers and ways of handling learners with special needs. Therefore, it is necessary to examine the problematic of shadow teachers in handling the students with special needs in SDN of Gadang 2 Banjarmasin.

\section{METHOD}

This approach uses a qualitative approach. The selection of qualitative approach is considered in accordance with the problems to be studied because it wants to describe the objective conditions and in a natural setting, and expected with this qualitative approach the researcher can decrypt the real condition of how the problematic of shadow teachers in SDN of Gadang 2 Banjarmasin in-depth and thorough by using interview or observation techniques that involve the researcher as the core instrument in the field. The technique of collecting data in this research is an interview, observation, and documentation. Techniques of analysis of the research used the interactive analytical model of [5].

Triangulation used in the study as follows: source triangulation is digging the truth of certain information through various sources to obtain data. Collecting and checking data is done to the teacher of classroom companion and teacher of class 1, class 2 and class 3 SDN Gadang 2 Banjarmasin. Triangulation method in this research is done by checking data about role ability and task of companion teacher obtained by interview method, observation, and documentation. Triangulation of time is the collection of data performed at different times and occasions.

\section{RESULT AND DISCUSSION}

\section{A. Shadow Teacher's knowledge about inclusive education setting in SDN Gadang 2 Banjarmasin.}

This research shows that shadow teacher from grade I, II, and III in SDN of Gadang 2 Banjarmasin already have knowledge about inclusive education.

The knowledge that shadow teacher has about the meaning of special education is that inclusive education is education without discrimination and accept all students (including special need students\}. Inclusive education is without discrimination education. Education that gives services for all children without mending physical, intellectual, social, emotion, economy, gender, tribe, culture, living places, language, and others.

The shadow teacher thinks that the function of inclusive education in SDN of Gadang 2 Banjarmasin is that all students can go to school based on their ability or their potential; makes the students understand each other. Another function is to ensure all students have the same chances and access to get education service based on what they need and with good quality in every path, type, and education ladder.

The shadow teacher said in SDN of Gadang 2 Banjarmasin inclusive education have lots of benefits, in one example a special need student can interact with another student, the parents feel relaxed because the shadow teacher that handle the special need student, the school will be known as one alternative in society. Based on the theory that the benefits of inclusive education for school are that the school's image is getting better, school is more open, friendly and not discriminating. School can increase the education quality comprehensively for every student.

\section{B. The role and duties of a special escort teacher at SDN Gadang 2 Banjarmasin.}

Special assistant teachers in SDN of Gadang 2 Banjarmasin in carrying out the role and duties as special escort teachers are implemented quite optimally. This can be seen by the special companion teachers compiling their own teaching materials adapted to the ability of learners with special needs and seeing their characteristics. Special escort teachers in performing roles to assist learners with special needs are not only centered when engaging in the classroom but also outside the classroom activities, such as learning to socialize with their friends. It is important that the role of a special escort teacher be essential to creating the expected inclusive school. Special assistant teachers at SDN of Gadang 2 Banjarmasin in performing and Potential of Intelligence and/or Special Talent explained that the education unit of inclusive education providers uses educational unit level curriculum that accommodates the needs and abilities of the learners accordingly with talent, ask and potential. Then it is also explained that learning needs to consider the principles of 
learning tailored to the learning characteristics of learners. Similarly, the assessment explained that the assessment of learning results refers to the curriculum concerned. Their role does not cooperate with regular teachers in preparing teaching materials. It is the regular teacher who determines the material then communicates to the special escort teacher, so that the special escort teacher can plan what can be done to the special needs students who are accompanied. This is in accordance with the [1] on Inclusive Education for Students with impairment and having the Potential of Intelligence and/or Special Talent explained that the educational unit of the inclusive education provider uses an educational unit level curriculum that accommodates the needs and abilities of learners according to their talents, demands, and potentials. Then it is also explained that learning needs to consider the principles of learning tailored to the learning characteristics of learners. Similarly, the assessment explained that the assessment of learning results refers to the curriculum concerned.

The provision of special services to Special Need Student is contained in Individual Education Program (IEP). However, the results of interviews and field observations show that in SDN of Gadang 2 Banjarmasin, GPK performs the task of accompanying the ABK only following the direction of the regular teacher and tending to force the crew to follow the same learning with the students in general. PPI not made by GPK in SDN of Gadang 2 Banjarmasin. In accordance with the theory, problematic means things that cannot be solved, which it can cause problems [5]. The roles and tasks performed by special escort teachers at SDN Gadang 2 Banjarmasin, namely:

a. Assist classroom teachers in preparing special needs students

b. Guiding learners to complete the tasks of students with special needs

c. Redirecting the obsession of learners with special needs for a particular object

d. Reducing learners with special needs behave repetitively

Special assistant teachers at SDN Gadang 2 Banjarmasin already have knowledge of the task and role of being a special companion teacher. However, in the realization, there are some main tasks that are not implemented such as the creation of individual education programs (IEP) and the absence of cooperation between regular teachers with special companion teachers in determining teaching materials. While the special escort task is to help class teachers prepare activities, guide the completion of tasks of students with special needs, preparing structured play (in or outside the classroom), divert obsessions of students with special needs on certain objects, reducing learners with special needs repetitive behavior, as well as with classroom teachers and special tutors reporting progress on learning [6].

The above shows some of the roles and duties of special accompaniment teachers that are not implemented in SDN of Gadang 2 Banjarmasin, among which is a special companion teacher does not cooperate with regular teachers in preparing teaching materials, GPK does not make the PPI program so
GPK just follow the direction of the teacher delivered regularly so learning for $\mathrm{ABK}$ tends to be forced. Meanwhile, based on the theory of special mentors Teachers are teachers who have a background of S1 PLB and/or teachers who have followed the Inclusive Education Training. Special counselors do not serve as classroom teachers, subject teachers, and counseling teachers, but perform the task of being a special teacher related to the needs of children with special needs. Special counselors carry out face-to-face learning at least 6 hours/week, the rest served as a special tutor [7].

\section{Coordination of special escort teachers and regular teachers in handling learners with special needs in planning and learning process at SDN Gadang 2 Banjarmasin.}

The implementation activities of the planning and learning of the provider of inclusive education should be tailored to the characteristics of learners with special needs. In the implementation of planning and learning in inclusive schools' special escort teachers and regular teachers are the components that play an important role in these activities. Implementation of inclusive education planning and learning will not work well in the absence of coordination between special escort teachers and regular teachers.

Implementation of identification at SDN of Gadang 2 Banjarmasin special escort teachers is not involved in the identification and assessment process, whereas special companion teachers have an extraordinary educational background so that they know more about the characteristics of learners with special needs based on their disabilities. The process of identification and assessment in the school requires that students with special needs carry a letter from a psychologist. So, the companion teacher was never involved. Whereas according to the theory of Identification is an activity or effort used to find children with special needs according to the type of disorder or in accordance with problems/disorders.

The goal is to help solve problems faced by children with special needs so that the development is achieved in accordance with its potential. How to identify can be done by the teacher of each child together with other teachers. While the assessment is a process of gathering information about the development of learners by using appropriate tools and techniques to make educational decisions regarding placements and programs for learners. Through the assessment can be known what capabilities they already have, what has not or weaknesses and what the needs of learners, so that can be designed learning programs in accordance with the needs of learners.

The educational principles adapted to the general education unit and the vocational education unit of the inclusive education setting led to considerable demands and adaptations to teachers in the school. To implement it, in a public education unit or a vocational education unit, it is necessary to develop a flexible curriculum, namely adjustments to curriculum components such as objectives, content or materials, processes and evaluation or assessment. The implementation of flexible curriculum is not realized in SDN 
Gadang 2 Banjarmasin. This is due to the lack of knowledge of special escort teachers on how flexible curriculum suits their abilities. In addition, there is no good cooperation and communication between regular teachers and special escort teachers.

Planning and learning activities are one of the efforts in creating inclusive education as expected so in the planning and learning process not only learners who follow the system but the system that follows the learners. The process of inclusive learning activities at SDN of Gadang 2 Banjarmasin runs quite well. Based on the results of GPK observations and regular teachers are able to cooperate in providing interventions for learners with special needs to learn and able to work together to create a classroom atmosphere conducive to learning. However, in the process of learning activities, there is no adjustment of learning materials with the ability of learners with special needs so that the special assistant teachers help many students with special needs in solving the problem.

In this regard schools of inclusive education providers may seek cooperation with local governments and other stakeholders to facilitate or present teachers of special mentors and various training for specialist teachers, regular teachers, and principals for planning and learning activities for learners with special needs runs optimally.

\section{CONCLUSION}

Based on the results of research and discussions that have been described, it can be concluded that the problematics of shadow teachers in handling students with special needs in SDN of Gadang 2 Banjarmasin are as follows:

1. Specific shadow teachers have general knowledge of inclusive education, shadow teachers know that basically, inclusive education is non-discriminatory education; shadow teachers also have knowledge of the objectives, functions, and benefits of inclusive education.

2. Shadow teachers carry out their roles and duties in assisting children with special needs based on the characteristics and abilities of learners. However, shadow teachers do not cooperate with regular teachers in preparing teaching materials.

3. Coordination of shadow teachers and regular teachers in dealing with students with special needs is lacking. Shadow teachers are not involved in the identification and assessment process. The implementation of a flexible curriculum is not realized, because of the lack of knowledge of shadow teachers about the curriculum that suits the needs of learners.

\section{REFERENCES}

[1] Peraturan Menteri Pendidikan Nasional Nomor 70 Tahun 2009 tentang Pendidikan Inklusif, 2009

[2] Undang-undang Republik Indonesia Nomor 20 Tahun 2003 tentang Sistem Pendidikan Nasional bab IV pasal 5, 2003

[3] D. Kustawan, Manajemen Pendidikan Inklusif, Jakarta: Luxima, 2013

[4] Tarmansyah, Inklusif (Pendidikan Untuk Semua), Jakarta: Depdiknas, 2007
[5] M.B. Miles, and A. M. Huberman, Qualitative Data Analysis, Thousand Oaks: Sage, 1994

[6] Depdikbud, Kamus Besar Bahasa Indonesia, Jakarta: Bulan Bintang, 2002

[7] Y. Hasyim, "Pendidikan Inklusif di SMKN 2 Malang," Jurnal Kebijakan dan Pengembangan Pendidikan, 2, 2013, pp 112-121. 